\title{
Role of Women in Peace Initiatives
}

\section{Nwadinobi EA*}

Social Development Direct, 4th Floor, Mill House, Little London, 8 Mill Street, London, SE1 2BA, UK

\begin{abstract}
The study seeks to support the work of the Nigeria Stability and Reconciliation Programme (NSRP) and more specifically the aspect of the programme that focuses on Women and Girls. The framework within which the work on Women, Peace and Security operates is the United Nations Security Council Resolution on women, peace and security (UNSCR 1325). Excerpts of this study will feed into the planned refresh of the National Action Plan (NAP) 1325. It is anticipated that the research will also be useful for the implementation of all programmes and interventions that seek information in the area of Women, Peace and Security in Nigeria. What are the factors impeding actualization of the WPS agenda, what are the areas of least resistance, who are the key stakeholders and how can things be improved for the future.
\end{abstract}

Keywords: System; Security; Leadership; Community; Laws; Development

\section{Introduction}

The Nigeria Stability and Reconciliation Programme (NSRP) is a five year programme funded by the UK Department for International Development (DFID). It seeks to deliver interventions to reduce the impact of violent conflict and to promote reconciliation processes. Consisting of four 'outputs', the programme operates at national level and in eight focal states across four zones of Nigeria, namely, Bayelsa, Borno, Delta, Kaduna, Kano, Plateau, Rivers and Yobe States.

Strategic conflict assessments [1,2] and conflict mapping work undertaken by NSRP have identified a wide range of factors shaping conflicts locally [3]. All zones experience violence as a result of disputes over land and water, access to (government) resources including jobs, and over chieftaincy titles. Religious tensions and militancy amongst Muslims and Christians have been particularly pronounced in the North, but are negatively affecting intergroup perceptions in all parts of the country. Issues of social exclusion fuel resentment and reduce alternatives to violence. This is evidenced by young men's vulnerability to recruitment by armed groups or gangs, the exclusion from conflict management mechanisms experienced by women, girls, male youth and 'non-indigenes' and a security sector that is often viewed as-atbest-unresponsive to the needs of the majority of the population.

It is well known that women and girls are profoundly affected by violent conflict. As well as experiencing the same as their male counterparts, their experience is different and they experience particular, gender-based violations or abuse of their human rights. For example, conflict-induced displacement has a differential impact on women, men, girls and boys, while the type of violence experienced during violent conflict frequently differs according to gender as well as other factors such as age and ethnicity. The Beijing Declaration and Platform for Action in paragraph 112 states "Violence against women both violates and impairs or nullifies the enjoyment by women of their human rights and fundamental freedoms. In all societies, to a greater or lesser degree, women and girls are subjected to physical, sexual and psychological abuse that cuts across lines of income, class and culture".

According to the 2012 Gender in Nigeria report, Nigeria's 80.2 million women and girls have significantly worse life chances than men and also their sisters in comparable societies. Violence compounds and reinforces this disadvantage and exclusion.

Women and girls are, however, largely excluded from participating in conflict management, mediation or inter-group negotiations. In some areas, women are almost universally excluded from public life per se, a situation that may be exacerbated in situations of violent conflict [4].

On the other hand, women have the capacity to take action with regard to conflict and in some areas have already done so. The challenge for both national and international programmes, therefore, is to remove the obstacles to women's effective participation and organising.

\section{Aims of This Study}

In 2012, a study was done by the Nigeria Stability and Reconciliation Programme (NSRP) on the role of women in peace building titled "The role of women and girls in peace initiatives in Nigeria". This paper is an update to the study providing insights to some changes that have occurred in the intervening period [5].

\section{Methodology}

The study is based on

(a) A desk review of available literature;

(b) Information gathered by NSRP Regional Managers and staff in NSRP's eight focal states and

(c) Interviews with relevant personnel (Table 1). This information is gained from all levels of Nigeria's government: Federal, state and local government area (LGA).

\section{History}

Historically, the situation for women in Nigeria has been one of marginalisation. The constitution speaks of gender equality which is not practiced in reality. When the Presidential Technical Committee on the Review of the Constitution was set up by the President on $19^{\text {th }}$ October, 1999, women were completely excluded but as a result

*Corresponding author: Eleanor Ann Nwadinobi, Social Development Direct 4th Floor, Mill House, Little London, 8 Mill Street, London, SE1 2BA, UK; E-mail: elenwad@yahoo.co.uk

Received May 04, 2017; Accepted June 05, 2017; Published August 31, 2017

Citation: Nwadinobi EA (2017) Role of Women in Peace Initiatives. Intel Prop Rights. 5: 195. doi: 10.4172/2375-4516.1000195

Copyright: ( 2017 Nwadinobi EA. This is an open-access article distributed under the terms of the Creative Commons Attribution License, which permits unrestricted use, distribution, and reproduction in any medium, provided the original author and source are credited. 


\begin{tabular}{|l|l|l|}
\hline Sr. No & Name & Designation/Organisation \\
\hline NSRP Team & Haj Hamsatu Allamin & \\
\hline 1 & Amin Buba & Regional Manager North East \\
\hline 3 & Ineba Bob- Manuel & Regional Manager North West \\
\hline 4 & Regina Afiemo & Regional Manager Niger Delta \\
\hline 5 & Chitra Nagarajan & Regional Manger Middle Belt \\
\hline 6 & Kim Toogood & Gender Adviser \\
\hline Key Informants & Dame Pauline Tallen, (OFR) & Peace building Adviser \\
\hline 7 & Maryam Uwais & \\
\hline 8 & Hajia Atine Abdullahi & Former minister of State Science and Technology and former Plateau Deputy Governor \\
\hline 9 & WPS network Bayelsa & Special adviser to President for Social Protection Plan \\
\hline 10 & WPS network Rivers & Chief executive of Voice of Women, Divorcees and Orphans (VOWAN) \\
\hline 11 & Stakeholders at National symposium on UNSCR 1325 & MoWASD invitees \\
\hline 12 & Katsina & NSRP Partners \\
\hline
\end{tabular}

Table 1: Interviews with relevant personnel.

of outcry by the civil society, the membership of the committee was increased to include women [6].

The 1999 Constitution of the Federal Republic of Nigeria states [7] that 'The security and welfare of the people shall be the primary purpose of government'. The Constitution also states that 'In furtherance of the social order, every citizen shall have equality of rights, obligations and opportunities before the law' [8] creating a basis for women's and girls' equal participation in public life, including in matters to do with peace and security. It is also a universal principle that the primary responsibility for protecting security and human rights lies with national governments.

In addition to the universal principles of non-discrimination and that the state bears primary responsibility for the security and human rights of its citizens; Nigeria is a state party to major human rights instruments. These include both the UN Convention on the Elimination of All forms of Discrimination against Women and the African Charter on Human and People's Rights and its Protocol on the Rights of the African Woman, although neither has yet been domesticated.

Nigerian women are constantly called upon and indeed see it as their duty to maintain peace in the home, compound or in the extended family. These informal roles are recognised and expected of women by all and sundry, including predominantly male traditional and religious institutions. However, when it comes to more formal initiatives towards the actualisation of peace they are left out. Women are missing in peace commissions, committees, or as signatories to peace pacts.

The United Nations Security Council (UNSC) adopted Resolution 1325 in 2000 acknowledging the under representation of women in peace processes and calling on member states to take action to rectify this. Nigeria came on board in August of 2013 by launching her National Action Plan 1325 with the support of the Nigeria Stability and Reconciliation Programme (NSRP) and UN Women. This resolution was followed most recently by Resolution 2242 in 2015.

\section{Resolution 2242 (2015)}

Adopted by the Security Council at its 7533rd meeting, on 13 October 2015, recognizing the significance of the fifteen-year anniversary of resolution 1325 (2000), the progress made as well as the opportunity and need for far greater implementation of the women, peace and security agenda, remaining deeply concerned by the frequent underrepresentation of women in many formal processes and bodies related to the maintenance of international peace and security, the relatively low number of women in senior positions in political, peace and security-related national, regional and international institutions, the lack of adequate gender-sensitive humanitarian responses and support for women's leadership roles in these settings, insufficient financing for women, peace and security, and the resulting detrimental impact on the maintenance of international peace and security, The Security Council Urges Member States, in light of the High-level Review, to assess strategies and resourcing in the implementation of the women, peace and security agenda, reiterates its call for Member States to ensure increased representation of women at all decisionmaking levels in national, regional and international institutions and mechanisms for the prevention, and resolution of conflict, encourages those supporting peace processes to facilitate women's meaningful inclusion in negotiating parties' delegations to peace talks, calls upon donor countries to provide financial and technical assistance to women involved in peace processes, including training in mediation, advocacy [9].

In addition the Committee on the Elimination of Discrimination against Women (CEDAW) in October 2013 came out with a General recommendation No. 30 [10] on women in conflict prevention, conflict and post-conflict situations.

"Participation (arts.7-8) 42. While women often take on leadership roles during conflict as heads of households, peacemakers, political leaders and combatants, the Committee has repeatedly expressed concern that their voices are silenced and marginalized in postconflict and transition periods and recovery processes. The Committee reaffirms that the inclusion of a critical mass of women in international negotiations, peacekeeping activities, all levels of preventive diplomacy, mediation, humanitarian assistance, social reconciliation, peace negotiations at the national, regional and international levels as well as in the criminal justice system can make a difference. At the national level, women's equal, meaningful and effective participation in the various branches of government, their appointment to leadership positions in government sectors and their ability to participate as active members of civil society are prerequisites for creating a society with lasting democracy, peace and gender equality".

\section{Barriers to Women's Participation}

Barriers to women's participation include cultural and traditional 
practices. Other barriers- include lack of money, access to loans as well as the more structural issues like fear of women being away from home and playing non stereotypical roles.

At 5.9\%, Nigeria ranks significantly below the sub-Saharan African average of $20 \%$ regarding women's representation in the national legislature [11]. At 5.9\% female representation in the Federal House of Representatives (the lower chamber) stands below neighbouring Niger (12.3\%), DR Congo (8\%), Ethiopia (27\%) and Cameroon (20\%) as well as Uganda, South Africa and Rwanda (34\%, 43.2\% and 56\% respectively) [12]. The profile does not improve at the Senate (upper legislative house) where Nigeria at $9 \%$ stands below the global average of $15 \%$ [13]. The situation in the North of Nigeria is worse. In a study commissioned for DFID [14] in Yobe, Bauchi, Zamfara and Jigawa states, the findings were that 'women were only $2 \%$ of political office holders at state level in 2007'.

The attitudes towards women in leadership are evident in a 2015 study "Nigerian men and gender equality survey (NiMAGES)". In the NiMAGES study while the percentage of male survey respondents who agreed that both men and women can make equally good leaders was $77 \%$, those who said that men should be elected rather than women because they make better leaders were 56\% [15]. The Being a Man in Nigeria study also looked at attitudes towards women in politics $-30 \%$ men believed Female politicians sometimes deserve to be harassed to discourage them from going for men's positions [16].

In another 2016 study 'Teacher Education, Teacher Practice, Approaches to Gender and Girls' Schooling outcomes" funded by MacArthur and co-ordinated by the British Council [17], views on women's leadership between men and women student teachers were quite polarised. Those who strongly agree that women have the right to hold leadership position in the community were $60 \%$ female and $20 \%$ men. Those who strongly agree that a female president can be as effective as a male president were female $55 \%$ and male $15 \%$ (Figure 1).

The other barriers-include lack of money/time etc. as well as the more structural issues e.g., around women being away from home etc.? The factors already mentioned above, mean that any participation by women is in itself a significant achievement. While it would be ideal to examine the impact of women's involvement as women, this assumes
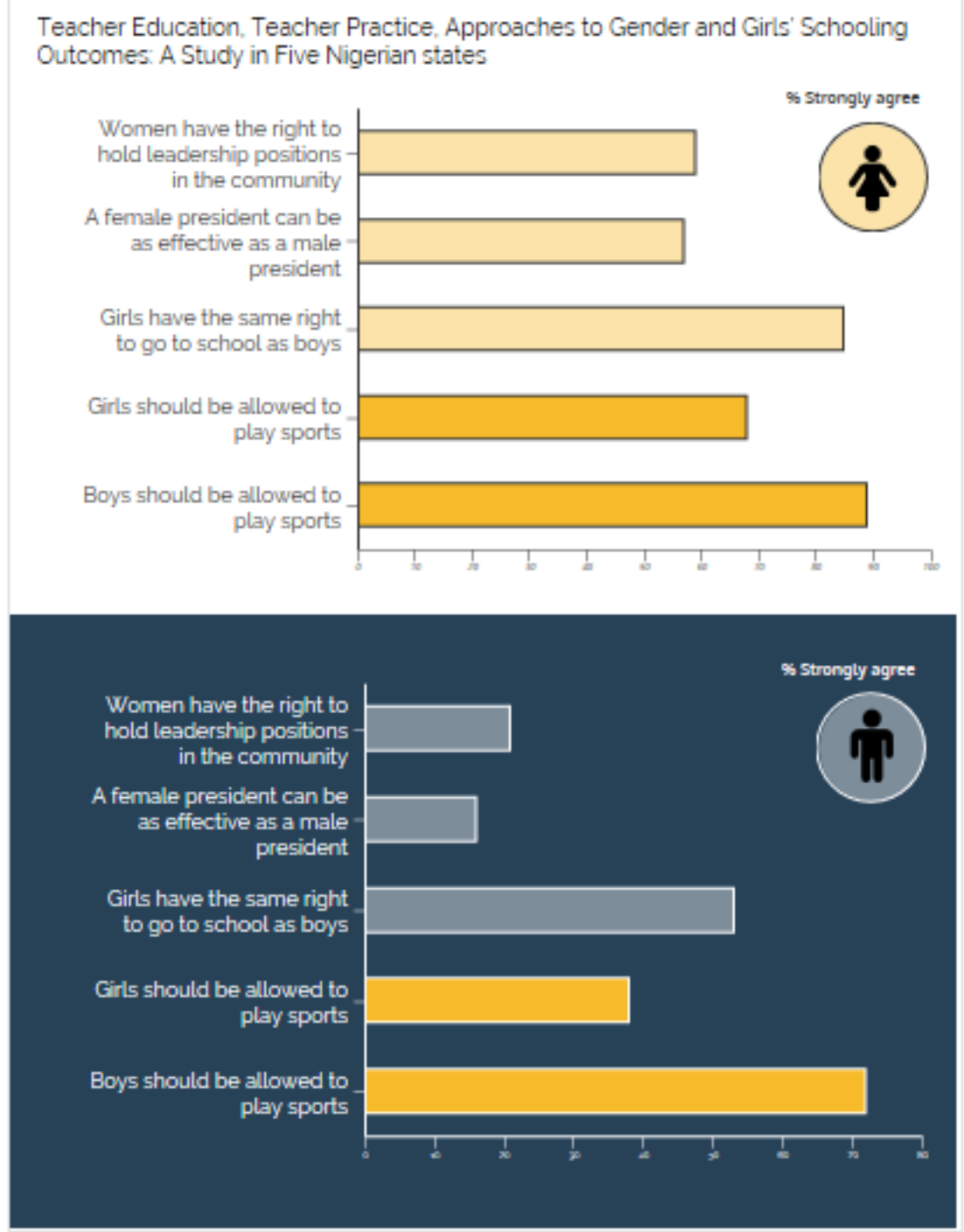

Figure 1: A study in five Nigerian states. 
a level of participation above that of most Nigerian institutions. It also risks subjecting women to greater scrutiny than their male counterparts; it is rare to ask whether men have had an impact in institutions as men. This study has found, nevertheless, that when women are included, they can make a difference to the process and results of conflict mechanisms.

A word of explanation about women's leadership is helpful here: Women's leadership takes many forms. It may include active participation in public institutions such as the legislature or panels of inquiry; activism using traditional roles such as motherhood or marriage or activism based on women's particular experience such as gender-based violence. Women's leadership, particularly in situations where women are systematically silenced and made invisible in the formal, public domain, may also mean that women use their informal networks and organisation such as loans committees, mothers' groups or neighbourhood alliances to speak out on conflict, to resolve conflicts non-violently or to influence the conduct of more formal mechanisms. This is not to say that 'behind the scenes' participation is adequate, but to state that in seeking to identify and support women's active role in peace building, it is often necessary to look beyond the formal and overt to the roles that women play in communities.

\section{Peaceful Protests by Women}

The Women without walls Initiative is an initiative of Pastor Esther Ibanga in Plateau State, Nigeria. She mobilized a peaceful protest march in March 2010; of about one hundred thousand Christian women within the state came out to lend their voices to putting a stop to the killings. According to Ibanga" We marched the streets of Jos to the State House of the Assembly and Government House dressed in black, expressing our grief over the wanton loss of human lives, especially those of women and children, and demanding that the government fish out the perpetrators of this evil and bring them to justice. The protest brought women to the forefront of the call for peace and for putting an end to violence in Plateau State. In response to the protest march by Christian women, Muslim women held their own peaceful protest demanding that the killings of Muslims in Jos also be stopped, as these women, too, had lost loved ones in the violent killings. In spite of the two protest marches, the killings continued. On the premise that we would be more effective if we joined forces, I decided to reach out to the Muslim women, enjoining everyone, irrespective of religion and tribe, to come together as one body in the fight against ethno religious violence" [18]. Women without walls continues to reach out to women across the religious divide.

Women mobilized in their hundreds from the adjourning Local Governments of Enugu-North, Enugu-East, Udi and Ezeagu Local Governments Areas of Enugu state on a protest march to the state government. "Having complained to the law enforcement agencies to no avail, the pastoralists who are usually armed with sophisticated weapons have become even more daring, defying even the community vigilante groups. Women and young men are now afraid to go to the farm unless they are in groups for fear of rape or outright killing" [19].

Women in Borno State including those belonging to the Women, Peace and Security Network organised a protest to the Shehu of Borno when the attacks in the North East started. They were the first, to condemn the abduction of girls from Government Secondary School, Chibok in Borno State. In a press statement by Hauwa Biu, who acted as the spokesperson of both the Borno women and the Rights group, said that the abduction violates the girls' human rights. She also said that the act is a crime against humanity, prohibited under the international humanitarian law [20].

In Biu, in Borno State, women alongside their Emir came out with sticks and stones to chase out members of JAS [21]. Women blocked the gates of a military base to stop their husbands going to fight boko Haram S.

In August 2014, about 300 women and 500 children gathered for two days at the gates of a military base in the Borno State capital, claiming that their spouses were ill-equipped to take on the Islamist militants. One soldier who spoke on condition of anonymity said that the troops in the barracks in Maiduguri relied on run-down equipment. "Our wives are speaking our minds... we are grossly underequipped," the soldier said. "Our guns are weak and armoured carriers not serviceable" [22].

Nassarawa widows, In May 2014, over one year after over 60 policemen who were brutally murdered in an ambush by the Ombatse cult members in Nasarawa State, their widows, most of them young women, took to the streets to protest the deaths of their husbands.

The widows were joined by hundreds of sympathizers and together they created a chaotic traffic situation at Squadron 38 Mobile Base, Ubbe Junction, as they blamed the state governor for exposing their husbands and breadwinners to undue risks by sending them on a highly risky assignment, without the requisite intelligence backup.

Governor Al-Makura sympathized with the widows and assured them that the perpetrators "shall surely be brought to book," just as he also promised that government would compensate them [23]

Due to their persistence they were eventually received cheques of about 450,000 naira each as compensation in December 2014 from the Northern Governors Forum.

Women staged peaceful protests asking for release of corpses following the Shiite uprising in Kaduna State. The Sisters Forum of the Islamic Movement of Nigeria staged a peaceful protest to demand for the immediate release of their leader, Sheik Ibraheem El-Zakzaky and his wife. The women marched to the Secretariat of the Kaduna State Council of the Nigeria Union of Journalists on Tuesday in northwest Nigeria. According to the spokesperson of the Forum, Aisha Hassan, the group also wants the immediate release of the corpses of members of the Islamic Movement of Nigeria, who were killed during a clash with soldiers [24].

\section{Landmark Appointments of Women}

- Justice Aloma Mariam Mukhtar is the former Chief Justice of Nigeria and served from July 2012 to November 2014. In her career, Mukhtar has been many firsts: she is the first female lawyer from Northern Nigeria, first female judge of the High court in Kano state judiciary, the first female justice of the court of Appeal of Nigeria, the first female justice of the Supreme Court of Nigeria and the first female Chief Justice of Nigeria [25]

- The Inspector General of Police, Solomon E. Arase, appointed Acting ACP Olabisi Alofe Kolawole as the first female police officer to be appointed as National Police spokesperson. "This appointment is geared towards harnessing the enormous potentials among Nigerian female Police officers," Arase said in a statement signed by CSP Abayomi Shogunle, the deputy Force Public Relations officer [26].

- Recently a panel of inquiry was set up in Kaduna state. The Kaduna State Government has announced the composition of the 
Judicial Commission of Inquiry into the 12th-14th December 2015 clashes in Zaria between the Islamic Movement in Nigeria and the Nigerian Army. The judicial commission of inquiry is established under Section 2 of the Kaduna State Commission of Inquiry Law, 1991.

"In a statewide broadcast last month, Governor El-Rufai had promised to establish a judicial commission of inquiry into the Zaria clashes, as a matter of utmost importance to the public interest. During the broadcast, the governor regretted the loss of lives and detailed what the Kaduna State Government had learnt about the immediate build-up to the clashes. The government also took steps to begin the prosecution of the people that were arrested during the clashes for crimes, including obstruction of public highways and possession of dangerous weapons. The women and juveniles among the detainees were swiftly processed and released. "The members of the Judicial Commission of Inquiry into the Zaria clashes were chosen for their professional competences as lawyers, jurists, scholars of religion, human rights activists, security experts and media practitioners". The Judicial Commission of Inquiry had 14 members with only two females. Mrs. Khadijah Hawaja Gambo -a gender rights activist, social entrepreneur and conflict resolution expert and Mrs. Desire Deseye Nsirim CP (Rtd.) -.a retired commissioner of police of Niger State [27].

- In Benue State, Justice Margaret Kpojime was head of the panel of enquiry Justice Margaret Kpojime who led the Judicial Commission of Inquiry into the income and expenditure of the state from 2007-2015 submitted the panel's report to Governor Samuel Ortom Monday, February 5th, 2015 where it made far reaching recommendations. The Commission recommended that 52 individuals and 10 corporate bodies should refund over N107 billion to the coffers of the state government. It also recommended deeper investigations and possible refund of over N44 billion from transactions they found not in compliance with the laid down financial guidelines. Kpojime told Governor Ortom that during the period covered by the assignment, N1. 21 trillion accrued to the state from about 27 identified sources out of which N802 billion was appropriated while N219 billion was expended but not appropriated [28].

\section{Women in Elected Positions}

In a recent ranking by the inter parliamentary union of women in National parliaments Nigeria ranked 130 out of 190 countries with $5.6 \%$ in the lower house and $6.5 \%$ in the house or senate. Rwanda ranking number one with $63.8 \%$ in the lower house and $38.5 \%$ in the upper house or senate [29].

Nigeria came close to having her first elected Governor of a State in the case of Aisha Alhassan of Taraba State. She had challenged the alleged improper conduct of her opponent in the primary elections. The court dismissed an appeal by the candidate of the All Progressives Congress, Aisha Alhassan, saying it lacked merit. A five-member panel of the Appeal Court in Abuja had on December 31 nullified the ruling of the Taraba State Election Tribunal on November 7, which declared Mrs. Alhassan winner of the April 11 election of the state [30]. Today, Aisha Alhassan is the Minister of Women Affairs.

In a community in the Niger Delta where it is unusual to have female community leaders, the chief pledged to allow the women duly elect their own representative to be recognised as The Woman Leader for Omokwa community. An election was done and Mrs. Diseph Isreal emerged the Woman Leader for Omokwa community on the 19th of September 2015.

Mrs. Diseph Isreal is a farmer and is married with children. Being married with children was a criteria decided upon by the community for the selection of the Woman Leader in Omokwa. Mrs. Diseph Isreal is also perceived as a peacemaker and a respectable woman in the community. The community recognised her as such because of the role she played in ensuring the peace and unity within her polygamous family was preserved. She thus far has participated as an active member of the Executive Council of Omokwa community and was part of the Executive Council members that inaugurated the Omokwa Youth Movement in 2015.

There have been reports of increased cult activities in Omokwa community in Abua-Odual Local Government Area. Feedback from the community also highlighted the increased incidence of armed robbery and kidnapping. This prompted the newly elected Woman Leader of Omokwa community to organize a town hall meeting, geared towards appealing to the good conscience of the various cult groups within the community, in order to restore peace to the community.

The Woman Leader, Mrs. Diseph, moved to organize a town hall meeting on the 7th of February 2016, in Omokwa community. She met with the Community Development Committee and the Chief's council members and the youth leadership body, who also supported the idea of the town hall meeting and made it possible. The town hall meeting was held to address the issue of cult activities and kidnapping in the community. The town hall meeting was attended by the CDC, Chief's Council, Youth Leaders and members of the community out of the two cult groups invited; only one was in attendance. The Chiefs and CDC members also addressed the cult group present. At the end of the day the cult group present made a commitment to desist from violent activities in the community.

The community is currently monitoring their activities to ensure they keep to their promise of not carrying out violent activities within the community.

\section{Women, Peace and Security Networks}

Globally, women are increasingly coming together as networks to bring about peace. In South Sudan for example, there are Women Peacekeeping Teams (WPTs). Members of the WPT are from the very community that they're trying to help, they are more readily accepted by people-and are thus able to solve many issues at ground level, without those from outside the region having to get involved [31].

NSRP has facilitated the coming together of Women Peace and Security (WPS) networks at Federal and in eight states. Their role is three pronged, firstly to sensitise members of the public on the existence and essential of the National Action Plan on Women Peace and Security; secondly to act as an interface with the State Ministries of Women Affairs towards the drafting of state action plans on WPS; and thirdly to monitor the implementation of the National and state action plans. As part of their sensitisation efforts WPS networks have achieved transformation as peace builders being active citizens who participate in media engagements.

WPSN in Borno made the first public press conference six days after abduction of over 200 Chibok school girls at a time when some members of the public were in denial regarding the incident.

WPSN have been active in domesticating and implementation of NAP, popularizing the internal commemorative days - international day of Women Widow, Refugees, Human Rights, Day of Peace etc., creating awareness and sensitizing the society on the flights of survivors and urging adequate response from Working in needs assessments and 
provision of humanitarian assistance in IDP camps. WPSN have also played a key role in the launch of state action plans on women, peace and security.

\section{Women as Combatants}

In Borno state, at the height of the JAS insurgency, women in Bama, Gwoza and Konduga had very little to wear themselves having given out all their clothes to men in order to disguise themselves to rescue them from their JAS captors. Two women paid using their own money to rescue civilians in Bama, until they were discovered and eventually killed.

Women hunters are also involved as combatants. In one account, Mai Bintu (translated as King Bintu) who was the daughter of a late king hunter, (who succeeded her father, being a hunter herself), on several occasions led the Civilian Joint Task Force (CJTF) on an operation against JAS in Bama. She then had to go into hiding in Kellumiri after the fall of Bama. Sadly, in retaliation JAS captured her daughter and forced the daughter to reveal her whereabouts. Mai Bintu was then trailed, captured taken to Bama and slaughtered in front of her community.

In February 2016, the daughter of a well-known hunter, the late Mai Durma, captured five JAS members from the Sambisa Forest area and brought them to Maiduguri. On lookers rushed to the scene along Damboa road to catch a glimpse of the brave woman, holding tight to her den gun, surrounded by other hunters and with their captives laying on the ground before they handed them over to security agencies [32].

In Adamawa State, female hunters are all part of a civilian vigilante coalition known as Ibn Fadlallah's forces. Barely literate and armed with dane guns as well as bows and arrows, they risk lives helping the armed forces to hunt members of the sect in the jungles of the NorthEast states of Adamawa, Borno and Yobe. Ladi is part of the large army of hunters and CJTF which battled Boko Haram after it tried to install Amirs (leaders) in Maiha, a town in Adamawa State. Asked why she mustered the courage to join the effort, Ladi replied: "Boko Haram's days are numbered. We are not afraid and we are ever ready to fight them [33].

These accounts are limited to the conflict in the North East of Nigeria, however, there are accounts of female militants in the Niger Delta who are allegedly engaged in militancy and gang violence. In addition, Nigeria is the highest contributor to peace keeping forces in ECOWAS, and according to the Peace keeping contributor profile of February 2015, of the two thousand nine hundred and sixty one troops, two hundred and thirty three were women [34].

\section{Women Working to Stop Violence against Women in Elections}

NSRP teamed up with UN Women Situation room through its WPS network to monitor election violence in the 2015 Nigeria Elections. High profile women and role models made up the eminent persons group. As a means of instituting the initiative the Women Situation Room Nigeria (WSRN) was launched to ensure women's participation in peaceful electoral processes. The WSRN also has an all-female observer team for observing elections.

National Democratic Institute (NDI) came up with the stop VAWIE (Violence against Women in Elections). The brand Ambassador was Stephanie Linus who is a Nollywood movie star. She used her position as a Nollywood star to advocate for peace and being a role model to many in the campaign against election related violence. Unity in Bayelsa took her message of peace by dancing as a means of attracting the attention of community members. She was able to mobilise up to 500 people to listen to her message of peace which was to "stop violence".

\section{Women Peace Builders and Activists}

In Borno State, Hajiya Hamsatu Allamin has been the courageous voice as a peace builder and activist. Hamsatu who is the Regional Manager of NSRP lives and works in Maiduguri, Borno state. She had resisted all persuasions to move out of Borno even at the height of the insurgency. Apart from being the eyes on the ground regarding media reports which filtered out and needed verification, she has become the reference point for new actors wishing to operate in the North East of Nigeria.

Hamsatu made a historic presentation on behalf of the NGO Working Group on Women, Peace and Security at the UN Security Council open debate on SGBV in April 2015 and participated as a panelist at the UN Conference on Countering Violent Extremism in February 2016, both at the UN Headquarters in New York.

Above all, Hamsatu Allamin is a pioneer gender activist, advocate and human rights defender, who has not only provided leadership to African women and youth, but has motivated and mentored them to discover and develop their potentials in the post conflict development and peace building efforts across North Eastern Nigeria.

Recently, Hajiya Hamsatu was selected as one of the four outstanding peacemakers for the Women PeaceMakers Program at the Joan B. Kroc Institute for Peace and Justice (IPJ) at the University of San Diego (USD) for 2016.

Ann-Kio Briggs, Nigerian environmental and human rights activist. She is the founder and executive director of non-governmental organization Agape Birth rights. As of 2011, she was spokesperson of the Ijaw Republican Assembly (IRA) as well as the United Niger Delta Energy Development Security Strategy (UNDEDSS) 35. AnnKio recently condemned the attacks by a new group of Militants in the Niger Delta called the Niger Delta Avengers for their recent attacks on oil and gas installations which have resulted in power outages due to reduced supply of gas to power stations $[35,36]$.

Maryam Uwais, served as member on the Judicial Commission of Enquiry on Pfizer in Kano State and after the work of the Commission she donated all her entitlement to form and established Isa Wali Empowerment Initiatives. Today Isa Wali seeks to give the children and women of Nigeria an opportunity to escape from the cycle of poverty fostered by long-held traditional beliefs through economic empowerment programmes and access to healthcare [37].

Hajia Atine Abdullahi, Chief executive of Voice of Women, Divorcees \& Orphans (VOWAN) made significant efforts towards peaceful elections during the 2015 elections. These programs are:

- Conducted 53 Radio programmes to sensitise members of the public on peaceful elections featuring on Freedom Radio, wazobio Fm, Rahama Radio, Express Radio as well as social media on the individual's right to vote and how to prevent violence during elections.

- Community/radio awareness campaign on men to allow their wives to go out and vote as women also have the right to vote. 
- Awareness campaign to young people on the negative effect of violence during elections.

Hajiya Altine's peace interventions also include Identification of rape survivors and ensuring perpetrators are well prosecuted, rehabilitation of young people who abuse drugs. In addition to all these efforts, she provides a safe haven and counselling services to the rape survivors.

At a focus group discussion held in Katsina, to mark the Commemoration of the $15^{\text {th }}$ anniversary of the United Nations Security Council Resolution 1325, Hajiya Hassu Inko was recognized by stakeholders, both men and women, for her mediation initiatives [38].

According to Dame Pauline Tallen, (OFR) in Plateau state "While I was home I tried to unite the various ethnic groups and association in Shendam for peaceful co-existence as a member local govt. management committee. I used my position to use both wards heads and district heads to organize peace and unity forum. I also encourage peace clubs in primary, secondary and our tertiary institutions. The aftermath of the Yelwa/Shendam conflict of 2004 in the southern zone left the communities segregated along Muslim / Christian divide. Women from both religions were invited by me to form the pre campaign team preparing for our election in 2007. This is because the conflict had divided the people along religious lines.

I was appointed as the inter-faith matron for the inter-faith mediation centre (IMC) Kaduna's inter-faith Rice miller's Association. 2007-2011 - As Deputy Governor of Plateau State, I handled the mediation process of the conflict that erupted after the controversial 2008 chairmanship election of Jos North Local Government Council. The violence migrated into the hinter lands of most of the Northern zone of the state ,my interventions were in the forms of; Organising meetings with community leader's women, youth and religious leaders in my office; visiting conflict zones to call on warning parties to stop the violence; Directing relief materials to be taken to most affected areas; visiting internally displaced persons and encouraging them to be patient with government as it looks into their plight as an individual's [39]; Dame Tallen continues the personal relationship to dialogue severally with the herdsmen leadership on the conflict within the farming communities of Riyom and Barkin Ladi Local Government Areas.

\section{Community Participation of Women in Peace Building}

NSRP conducted a study on community conflict management mechanisms to determine types of traditional and cultural practices. Some individuals resort to both traditional religions and Christianity, depending on the nature of the case. The sulhu mediation process is often used by communities in the areas under study for settling disputes. Community leaders constitute the sulhu committee, which calls the disputants to the negotiating table and listens to the stories on both sides of the conflict. It is after listening to both sides that the sulhu elders offer their suggestions for resolving the conflict.

In some parts of Northern Nigeria, Alwali is an important mediator in family conflict. The alwali represents the father of a bride and groom during marriage. The alwali, is called upon to mediate conflict in marriages.

In a conflict analysis of Ekurede Urhobo community, neither women nor girls were involved or participated in community governance. The women are relegated and deprived from governance except for the Ewheya or Emete age groups. These are traditional women age groups responsible for discipline among women and also other rites such as marriages and festivals. The youth group of the community has no record of involvement of the female youths in its deliberations and activities though in the past, they had one female in the executive body.

In the conflicts experienced by the community, women have played a key role in resolving and preventing conflict. In the clash between the community and Itsekiris from Ajamimogha, women took to the streets of the community, beating drums and other objects chanting that they want peace and their children should desist from fighting. Most of them sent out their sons from the community for safety. They also went out massively to the King of Agbarha- Warri Kingdom asking for his intervention [40].

\section{Men Standing Up for the Inclusion of Women in Peace Building}

As part of the growing efforts to include men as part of the solution to prevent and end violence against women, the United Nations Secretary-General Ban Ki-moon launched in 2009 his Network of Men Leaders.

The Leaders in this expanding Network-current and former politicians, civil society and youth activists, religious and community leaders, cultural figures and other prominent individuals - work in their spheres of influence to undertake specific actions to end violence against women, from raising public awareness, to advocating for adequate laws, to meeting with young men and boys, to holding governments accountable. The Network supports the work of women around the world to defy destructive stereotypes, embrace equality, and inspire men and boys everywhere to speak out against violence [41].

At a meeting of stakeholders in April of 2016 looking at the rebuilding of Borno, NSRP made a presentation on the need to involve women in the physical and psychosocial rebuilding. It was refreshing to hear the following from the current Governor of Borno "We are going to liberate the women of Borno from the yoke of debilitating subjugation" - H.E. Governor Kashim Shettima.

\section{Key Findings}

Barriers to women's participation are real, perceived and deeply entrenched in the culture. Peaceful protests by women have been carried out in various parts of the country in an attempt to advocate for peace. Some of these protests have been across religious divides. Landmark appointments of women have occurred and serve as a great endorsement of the fact that women can hold high level appointive positions. Women in elected positions remain very low in number and this will take some time for change to occur and women are actively working to stop Violence against Women in Elections Women, peace and security networks have proved to be quite strong especially when it comes to joint action or joint advocacy. Women have been visible as local combatants especially in the North East of Nigeria where they have made efforts to stand up to insurgents as well as in peace keeping forces. Women peace builders and activists are individuals who stand out as peace advocates in their circle of influence and community participation by women in peace building remains the most convincing at grass roots level. Men standing up for the inclusion of women in peace building provide a formidable platform to breaking the stereotype that exists.

\section{Recommendations}

In order to achieve meaningful and influential participation of 
women in peace building initiatives, the following approaches are recommended:

- Full domestication and implementation of NAP 1325 and integration of related resolutions especially resolution 2242 (2015).

- Project interventions for young people in and out of school towards the actualization of leadership position by women and girls.

- Initiate and strengthen community dialogue on the advantages of women in peace Building.

- CSOs are to challenge and create demand when women are excluded from formal processes.

- Media reports should highlight where women's participation has been ignored.

- Identify and have a database of female peace champions that fit the post and profile them as suitable alternatives.

- Women and girl role models can volunteer to visit establishments of groups and can be individually twinned in a mentoring programme.

- Systematic monitoring of implementation of all relevant plans, policies and laws.

\section{Conclusion}

In conclusion, things are changing gradually in the area of women participating meaningfully and influentially in peace building processes. However the lack of policies that encourage women's participation and the mind-set that mediation and negotiation is the exclusive preserve of men, needs to change. This paper highlights areas where changes are occurring as well as areas where a lot more work needs to be done.

\section{References}

1. The Nigeria 3-year NAP was drafted and launched in August 2013. The process for refreshing the NAP is about to commence.

2. Francis $P$, Lapin D, Rossiasco $P$ (2012) Securing Development and Peace in the Niger Delta: A Social and Conflict Analysis for Change. Woodrow Wilson International Center for Scholars, Washington DC, pp: 1-178.

3. NSRP (2011) Conflict mapping studies for Borno, Yobe, Kano, Kaduna Plateau, Rivers, Bayelsa and Delta States.

4. For instance, girls are known to be kept away from school in the northern states when there is an upsurge in violent conflict.

5. http://www.nsrp-nigeria.org/wp-content/uploads/2013/05/Women-Peace-andSecurity-Study.pdf

6. http://www.gamji.com/article5000/NEWS5168.htm

7. http://nigeriaworld.com/focus/constitution/chapter2.html

8. http://nigeriaworld.com/focus/constitution/chapter2.html.

9. http://www.un.org/en/ga/search/view_doc.asp?symbol=S/RES/2242(2015).

10. http://www.ohchr.org/Documents/HRBodies/CEDAW/GComments/ CEDAW.C.CG.30.pdf.

11. http://www.undp.org/content/dam/undp/library/MDG/english/The_MDG_ Report_2012.pdf.

12. http://dailytimes.com.ng/article/nigeria-needs-more-women-politics-olurode.

13. Gender in Nigeria report (2012).Improving the lives of girls and women in Nigeria. Issues, Policies, Action. British Council Nigeria pp: 1-99.

14. Ladbury S (2011) 'Religion, exclusion and violence in Northern Nigeria' (REVINN) Final report to DFID.
15. "Nigerian men and gender equality survey (NiMAGES) (2015) Nigeria Country Report UK AID pp:1-78.

16. http://www.v4c-nigeria.com/being-a-man-in-nigeria-perceptions-and-realities/.

17. http://www.britishcouncil.org.ng.programmes/education/research-policyproects/macarthur-training-research.

18. http://www.kosei-shuppan.co.jp/english/text/mag/2015/15_789_8.html.

19. http://riverinenews.com/fulani-rapists-and-enugu-women-protest/

20. http://www.premiumtimesng.com/news/159205-borno-women-condemnabduction-school-girls.html.

21. This account was given by stakeholders including CJTF at a meeting in Borno.

22. http://www.aljazeera.com/news/africa/2014/08/military-wives-protest-bokoharam-deployment-201481214045252459.html.

23. http://ww.informationng.com/2013/05/widows-of-slain-policemen-stageprotests-as-police-arrests-rats-in-the-force.html.

24. http://www.informationng.com/2016/01/shiite-women-protest-detention-of-elzakzaky-wife.html.

25. https://en.wikipedia.org/wiki/Aloma_Mariam_Mukhtar.

26. http://thenewsnigeria.com.ng/2015/08/police-headquarters-gets-first-femalepro/.

27. http://saharareporters.com/2016/01/16/killing-shiites-kaduna-stategovernment-announces-members-judicial-commissioninquiry.

28. http://www.kapital929.fm/benue-kpojime-report-why-governor-suswam-leadsthe-pack-of-looters/

29. http://www.ipu.org/wmn-e/classif.htm.

30. http://www.premiumtimesng.com/news/headlines/198304-supreme-courtdashes-mama-tarabas-hopes-upholds-gov-ishakuselection.Html.

31. https://broadly.vice.com/en_us/article/meet-the-all-women-peacekeepingforce-of-south-sudan

32. Account from Haj Hamsatu Allamin. Regional Manager, NE, NSRP

33. http://newtelegraphonline.com/i-dont-fear-boko-haram-ladi-female-hunter/

34. http://www.providingforpeacekeeping.org/2015/04/24/peacekeepingcontributor-profile-nigeria/

35. https://en.wikipedia.org/wiki/Ann-Kio_Briggs_-_cite_note-briggs1-1.

36. http://www.informationng.com/2016/06/annkio-briggs-ndelta-avengers-fromsomalia.html.

37. http://www.girlsnotbrides.org/members/isa-wali-empowerment-initiative-iwei/.

38. The question asked during the FGD was "which female in Katsina State stands out as being an advocate for peace".

39. Excerpts from submission by Dame Pauline Tallen

40. A baseline assessment report on the six project impact areas in Ndokwaeast, Ughelli north and Warri south LGA A research by Mrs Rukevwe Ekakitie Uvietesivwi.

41. http://www.un.org/en/women/endviolence/network.shtml. 